\title{
DEVELOPMENT AND EVALUATION OF GASTRORETENTIVE FLOATING TABLETS OF A QUINAPRIL HCL BY DIRECT COMPRESSION TECHNIQUE
}

\author{
AUDUMBAR DIGAMBAR MALI*, RITESH SURESH BATHE \\ Department of Pharmaceutics, Sahyadri College of Pharmacy, Methwade, Sangola 413307, Solapur, Maharashtra, India \\ Email: maliaudu442@gmail.com
}

Received: 28 Apr 2016 Revised and Accepted: 19 Jun 2017

\begin{abstract}
Objective: The present study was undertaken with an objective to design, develop and evaluate gastro retentive floating tablets of an antihypertensive drug, quinapril $\mathrm{HCl}$, which release the drug in a sustained manner over a period of $12 \mathrm{~h}$.

Methods: In this research work, we used hydrophilic polymer hydroxypropyl methylcellulose (HPMC K4M), the gas generating agent sodium bicarbonate and citric acid at different ratios for the preparation of tablets. A $3^{2}$ factorial design was applied systematically; the amount of HPMC $\mathrm{K} 4 \mathrm{M}\left(\mathrm{X}_{1}\right)$ and the amount of citric acid $\left(\mathrm{X}_{2}\right)$ were selected as independent variables. The dependent variables chosen were percentage drug release at $6 \mathrm{~h}\left(\mathrm{Q}_{6}\right)$, percentage drug release at $12 \mathrm{~h}\left(\mathrm{Q}_{12}\right)$ and floating lag time. The high concentration of HPMC K4M and citric acid gives a sustained release for quinapril $\mathrm{HCl}$ floating tablets. The tablets were prepared by direct compression technique and evaluated for tablet thickness, hardness, weight variation, friability, floating lag time and In vitro drug release.
\end{abstract}

Results: The In vitro drug release indicated the floating dosage forms showed slower release when the concentration of HPMC K4M increases. Formulation F4 having ratio 25:8 (HPMC K4M: citric acid) was considered as an optimised formulation which shows satisfactory sustained drug release and remained buoyant on the surface of the medium for more than $12 \mathrm{~h}$. It can also conclude that floating drug delivery system of quinapril $\mathrm{HCl}$ can be successfully formulated as an approach to increase gastric residence time and thereby improving its bioavailability.

Conclusion: The developed effervescent based floating tablets are a promising floating drug delivery system for oral sustained administration of quinapril $\mathrm{HCl}$.

Keywords: Quinapril $\mathrm{HCl}$, Gastroretentive floating drug delivery, Citric acid, In vitro buoyancy, Direct compression, $3^{2}$ factorial design

(C) 2017 The Authors. Published by Innovare Academic Sciences Pvt Ltd. This is an open access article under the CC BY license (http://creativecommons.org/licenses/by/4.0/) DOI: http://dx.doi.org/10.22159/ijpps.2017v9i8.12463

\section{INTRODUCTION}

The oral drug delivery is most widely used routes of administration in all different routes that have been utilized for systemic delivery of drugs from the different dosage form. The oral route is considered most comfortable and most widely accepted by the patients because of its ease of administration, patient acceptance, and cost effective manufacturing process. An oral drug delivery system providing a uniform drug delivery can only partly satisfy therapeutic and biopharmaceutical needs, as it doesn't take into account the sitespecific absorption rates within the gastrointestinal tract (GIT). Therefore, there is a need of developing a drug delivery system that releases the drug at the right time, at the specific site and with the desired rate. Invariably, conventional dosage forms do not maintain the drug blood levels within the therapeutic range for an extended period of time. The concept of gastro retentive drug delivery system came from the need to localise the drug at a certain site in the body. It was suggested that compounding narrow absorption window drugs in a unique pharmaceutical dosage form with gastro retentive properties would enable an extended absorption phase of these drugs. Especially the site of drug absorption is mainly stomach or upper part of the small intestine, then it is necessary to retain the dosage form at the site of absorption, but the gastrointestinal transit is the limitation for such type of dosage forms [1]. Floating drug delivery is the most common route of drug delivery because of the easy of administration, patient compliance and flexibility in the formulations. To prolong the residence time of dosage forms within gastrointestinal tract until all drug is released at desired rate is one of the real challenges for oral controlled-release drug delivery system. In the present research work, gastro-retentive dosage forms gives more attention due to they can improve the performance of floating controlled release drug delivery systems. An optimum floating controlled release drug delivery system can be defined as a system which remains in the stomach for a sufficient time interval against all the physiological barriers releases active moiety in a controlled manner and finally is easily metabolized in the body. Physiological barriers like gastric motility and gastric retention time (GRT) act as obstacles in developing an efficient GRDF. Several technical approaches are currently utilized in the prolongation of gastric residence time, including high density, swelling and expanding, polymeric mucoadhesive, ion-exchange, raft forming, magnetic and floating drug delivery systems (FDDS), as well as other delayed gastric emptying devices $[1,2]$.

Quinapril $\mathrm{HCl}[(R S)-2-(4-(2-m e t h y l p r o p y l)$ phenyl) propionic acid] is phenyl propionic acid derivative/cyclooxygenase inhibitor from the class of nonsteroidal anti-inflammatory drug used in the treatment of fever, arthritis as an analgesic. In general, quinapril $\mathrm{HCl}$ also acts as a vasoconstrictor, having been shown to constrict coronary arteries and some other blood vessels mainly because it inhibits the vasodilating prostacyclin produced by cyclooxygenase-II enzymes. Quinapril $\mathrm{HCl}$ (marketed under the brand name Accupril by Pfizer) is an angiotensin-converting enzyme inhibitor (ACE inhibitor) used in the treatment of hypertension and congestive heart failure. A prodrug, it is converted to its active metabolite, quinaprilat, in the liver. Quinapril $\mathrm{HCl}$ inhibits angiotensin converting enzyme, an enzyme which catalyses the formation of angiotensin II from its precursor, angiotensin I. Angiotensin II is a powerful vasoconstrictor and increases blood pressure through a variety of mechanisms. Due to reduced angiotensin production, plasma concentrations of aldosterone are also reduced, resulting in increased excretion of sodium in the urine and increased concentrations of potassium in the blood. Quinapril $\mathrm{HCl}$ is indicated for the treatment of high blood pressure (hypertension) and as adjunctive therapy in the management of heart failure. It may be used for the treatment of hypertension by itself or in combination with thiazide diuretics, and with diuretics and digoxin for heart failure. Quinapril $\mathrm{HCl}$ has short half-life $(2 \mathrm{~h})$. To reduce the frequency of administration and to 
improve patient compliance, gastro retentive floating system formulation is desirable. Quinapril $\mathrm{HCl}$ is a nonpeptide, nonsulfhydryl prodrug that is de-esterified to quinaprilat (quinapril diacid), its major active metabolite following oral administration. Quinaprilat lowers blood pressure by antagonising the effect of the Renin-Angiotensin-Aldosterone System (RAAS). The RAAS is a homeostatic mechanism for regulating hemodynamics, water and electrolyte balance. During sympathetic stimulation or when renal blood pressure or blood flow is reduced, renin is released from the granular cells of the juxtaglomerular apparatus in the kidneys. In the blood stream, renin cleaves circulating angiotensinogen to ATI, which is subsequently cleaved to ATII by Angiotensin-Converting Enzyme (ACE). ATII increases blood pressure using a number of mechanisms. First, it stimulates the secretion of aldosterone from the adrenal cortex. Aldosterone travels to the Distal Convoluted Tubule (DCT) and collecting tubule of nephrons where it increases sodium and water reabsorption by increasing the number of sodium channels and sodium-potassium ATPases on cell membranes. Second, ATII stimulates the secretion of vasopressin (also known as Ant Diuretic Hormone or ADH) from the posterior pituitary gland. $\mathrm{ADH}$ stimulates further water reabsorption from the kidneys via insertion of aquaporin-2 channels on the apical surface of cells of the DCT and collecting tubules. Third, ATII increases blood pressure through direct arterial vasoconstriction. Stimulation of the Type 1 ATII receptor on vascular smooth muscle cells leads to a cascade of events resulting in myocyte contraction and vasoconstriction.

In addition to these major effects, ATII induces the thirst response via stimulation of hypothalamic neurons. ACE inhibitors inhibit the rapid conversion of ATI to ATII and antagonize RAAS-induced increases in blood pressure. ACE (also known as kininase II) is also involved in the enzymatic deactivation of bradykinin, a vasodilator. Inhibiting the deactivation of bradykinin increases bradykinin levels and may sustain the effects of quinaprilat by causing increased vasodilation and decreased blood pressure. Peak plasma concentrations of quinapril $\mathrm{HCl}$ occur within one hour following oral administration. The extent of absorption is at least $60 \%$. The rate and extent of quinapril $\mathrm{HCl}$ absorption are diminished moderately (approximately 25-30\%) when quinapril $\mathrm{HCl}$ tablets are administered during a high-fat meal [3-5].

The objective of the present research work of floating tablet containing quinapril $\mathrm{HCl}$ as a drug candidate which would remain in the stomach or upper part of GIT for prolonged period of time thereby maximizing the drug release at the desired site within the stipulated time with a view to improve bioavailability.

\section{MATERIALS AND METHODS}

Quinapril $\mathrm{HCl}$ was obtained as a gift sample from Marksans Pharmaceutical Ltd., Verna, Goa, India. HPMC K4M and carbopol 934p were procured from Colorcon Asia, Goa. Ltd. citric acid, sodium bicarbonate, lactose, magnesium stearate and talc were procured from SD Fine Chemicals, Mumbai.

\section{Drug excipients interaction study and identification}

FTIR spectroscopy study was carried out to detect any changes on chemical constitution of the drug after combining it with the excipients. The pure drug, drug-polymers combinations and formulations were subjected to FTIR studies. Potassium bromide, pure drug, and the polymers were heated to $105{ }^{\circ} \mathrm{C}$ for one hour to remove the moisture content if present in a hot air oven. Then in presence of IR lamp, potassium bromide was mixed with drug and or polymer in 9:1 ratio. Grinding in smooth mortar can effect mixing. The mixtures were then placed in the sample holder of the instrument and the spectra were taken.

\section{Infrared absorption spectroscopy}

To investigate any possible interaction between the drug and all excipients used (HPMC K4M, Citric acid, Carbopol 934P, Sodium bicarbonate, lactose, magnesium stearate and talc). Infrared spectra recorded on Bruker infrared spectrophotometer in $\mathrm{KBr}$ pellets.

\section{UV spectroscopy (determination of $\lambda$ (lambda) $\max$ and preparation of standard curve)}

$100 \mathrm{mg}$ of quinapril $\mathrm{HCl}$ was accurately weighed and dissolved in $0.1 \mathrm{~N} \mathrm{HCl}$ and made a volume up to $100 \mathrm{ml}$, made the concentration of $1000 \mu \mathrm{g} / \mathrm{ml} .1 \mathrm{ml}$ of solution was pipetted out and diluted with $0.1 \mathrm{~N} \mathrm{HCl}$ solution to make the concentration of $100 \mu \mathrm{g} / \mathrm{ml}$. From stock solution aliquot ranging from 0.5 to $2.5 \mathrm{ml}$ were pipetted out and diluted with $0.1 \mathrm{~N} \mathrm{HCl}$ to get concentration range 5 to $25 \mu \mathrm{g} / \mathrm{ml}$. The absorbance measured at $259 \mathrm{~nm}$ against the blank solution. The standard graph plotted by keeping concentration on the $\mathrm{x}$-axis and obtained absorbance on the y-axis.

\section{Formulation development}

\section{Formulation design}

Formulation design study is important for selection of appropriate excipients for preparation tablets. The HPMC K4M was used for trial preparation of tablets. The trial batches of tablets were prepared by direct compression technique using other commonly used excipients.

\section{Full factorial design}

A $3^{2}$ randomized full factorial design was constructed to study. In this design 2 factors were evaluated, each at 3 levels and experimental trials was performed at all 9 possible combinations. The amount of HPMC K4M $\left(\mathrm{X}_{1}\right)$ and citric acid $\left(\mathrm{X}_{2}\right)$ were selected as independent variables. The dependent variables chosen were percentage drug release at $6 \mathrm{~h}\left(\mathrm{Q}_{6}\right)$, percentage drug release at $12 \mathrm{~h}\left(\mathrm{Q}_{12}\right)$ and Floating Lag Time [6-8].

Table 1: Factorial design of the formulation

\begin{tabular}{|c|c|c|c|c|c|c|c|c|c|}
\hline \multirow[t]{2}{*}{ Coded values } & \multicolumn{9}{|c|}{ Batch code } \\
\hline & F1 & F2 & F3 & F4 & F5 & F6 & F7 & F8 & F9 \\
\hline $\mathrm{X}_{1}$ & -1 & -1 & -1 & 0 & 0 & 0 & +1 & +1 & +1 \\
\hline $\mathrm{X}_{2}$ & -1 & 0 & +1 & -1 & 0 & +1 & -1 & 0 & +1 \\
\hline
\end{tabular}

number of experiments $=9$

Table 2: Translation of coded values to actual values

\begin{tabular}{lll}
\hline Coded values & Actual values & $\mathbf{X}_{\mathbf{2}}$ \\
\cline { 2 - 3 } & $\mathbf{X}_{\mathbf{1}}$ & 20 \\
\hline-1 & 8 & 25 \\
0 & 12 & 30 \\
\hline 1 & 16 & 30 \\
\hline
\end{tabular}

number of experiments $=3$

Where $\mathrm{X}_{1}$-Amount of HPMC K4M, $\mathrm{X}_{2}$-Amount of citric acid, $\mathrm{Q}_{6}$-percentage drug release at $6 \mathrm{~h}, \mathrm{Q}_{12}$-percentage drug release at $12 \mathrm{~h}$ and Floating Lag Time. 
A statistical model incorporating interactive and polynomial term was used to evaluate the responses.

$$
\mathrm{Y}=\mathrm{b}_{0+} \mathrm{b}_{1} \mathrm{X}_{1}+\mathrm{b}_{2} \mathrm{X}_{2}+\mathrm{b}_{11} \mathrm{X}_{1}{ }^{2}+\mathrm{b}_{22} \mathrm{X}_{2}^{2}+\mathrm{b}_{12} \mathrm{X}_{1} \mathrm{X}_{2}
$$

Where $\mathrm{Y}$ is the dependent variable, $\mathrm{b}_{0}$ is the arithmetic mean response of the 9 runs, and $b_{i}\left(b_{1}, b_{2}, b_{12}, b_{11}\right.$ and $b_{22}$ is the estimated coefficient for the factor $\left.\mathrm{X}_{1}\right)$. The main effect $\left(\mathrm{X}_{1}\right.$ and $\left.\mathrm{X}_{2}\right)$ represents the average results of changing one factor at a time from its low to high values. The interaction term $\left(\mathrm{X}_{1} \mathrm{X}_{2}\right)$ show how the response changes when 2 factors are changed simultaneously. The polynomial term $\left(\mathrm{X}_{1}{ }^{2}\right.$ and $\left.\mathrm{X}_{2}{ }^{2}\right)$ are included to investigate nonlinearity.

\section{Preparation of quinapril $\mathrm{HCl}$ floating tablet}

Tablets were prepared by direct compression technology [9] using Karnavati Rimek Mini Press single punch machine. The tablets of different concentrations were prepared.

The drug, polymer, sodium bicarbonate, citric acid and lactose are weighed accurately and passed through mesh and blended for $10 \mathrm{~min}$. Then sieved materials were mixed with lubricant (magnesium stearate and talc) for 5 min mixed geometrically and compressed. The compositions details of floating tablets are given in table 3 .

Table 3: Composition of floating tablets of quinapril $\mathrm{HCl}$

\begin{tabular}{|c|c|c|c|c|c|c|c|c|c|}
\hline Ingredients (mg/tablet) & F1 & F2 & F3 & F4 & F5 & F6 & F7 & F8 & F9 \\
\hline Quinapril $\mathrm{HCl}$ & 20 & 20 & 20 & 20 & 20 & 20 & 20 & 20 & 20 \\
\hline HPMC K4M & 20 & 20 & 20 & 25 & 25 & 25 & 30 & 30 & 30 \\
\hline Citric acid & 8 & 12 & 16 & 8 & 12 & 16 & 8 & 12 & 16 \\
\hline Sodium bicarbonate & 60 & 60 & 60 & 60 & 60 & 60 & 60 & 60 & 60 \\
\hline Carbopol 934P & 10 & 10 & 10 & 10 & 10 & 10 & 10 & 10 & 10 \\
\hline Lactose & 22 & 18 & 14 & 17 & 13 & 9 & 12 & 8 & 4 \\
\hline Magnesium stearate & 5 & 5 & 5 & 5 & 5 & 5 & 5 & 5 & 5 \\
\hline Talc & 5 & 5 & 5 & 5 & 5 & 5 & 5 & 5 & 5 \\
\hline Total weight & 150 & 150 & 150 & 150 & 150 & 150 & 150 & 150 & 150 \\
\hline
\end{tabular}

number of experiments $=9$

\section{Pre-compression evaluation}

The granules were evaluated for flow property i.e. angle of repose, bulk density, tapped density, compressibility index (Carr's index) and Hausner's ratio using standard procedures [10-12].

\section{Post-compression evaluation}

The prepared tablets were evaluated for their physical parameters like hardness, thickness, weight variation, friability and drug content.

Hardness of the all tablet formulations was determined by Monsanto hardness tester and precision dial type hardness tester for each formulation the hardness of 5 tablets was determined, the average was calculated and presented with standard deviation. It is expressed in $\mathrm{kg} / \mathrm{cm}^{2}$. The thickness of tablets was important for uniformity of tablet size. Thickness was measured by using verniar caliper on 3 randomly selected samples [13-15].

Twenty tablets were randomly selected from each formulation and weighed individually to check for weight variation. Friability is the measure of tablet strength. Roche Friabilator was used for testing the friability using the following procedure. Twenty tablets were weighed accurately and placed in the plastics chamber that revolves at $25 \mathrm{rpm}$ for $4 \mathrm{~min}$ dropping the tablets through a distance of six inches with each revolution. After 100 revolutions the tablets were reweighed and the percentage loss in tablet weight was determined:

$$
\text { Percentage Friability }=\frac{W-W o}{W} \times 100
$$

Where,

Wo= initially weight

$\mathrm{W}=$ weight after friability

Percentages Friability of tablets less than $1 \%$ are considered acceptable $[16,17]$.

Twenty tablets each containing $20 \mathrm{mg}$ quinapril $\mathrm{HCl}$ was weighed crushed to powder and average weight was calculated. Powder equivalent to $10 \mathrm{mg}$ of quinapril $\mathrm{HCl}$ was transferred in $100 \mathrm{ml}$ volumetric flask. A $50 \mathrm{ml}$ of $0.1 \mathrm{~N} \mathrm{HCl}(\mathrm{pH} \mathrm{1.2)} \mathrm{was} \mathrm{added} \mathrm{and}$ sonicated for $15 \mathrm{~min}$. Then the solution was further diluted up to the mark with $0.1 \mathrm{~N} \mathrm{HCl}$. The solution was filtered using whatmann filter paper No. 41; first $5 \mathrm{ml}$ of filtrate was discarded. This solution was further diluted to obtain $20 \mu \mathrm{g} / \mathrm{ml}$ solution with $0.1 \mathrm{~N} \mathrm{HCl}$ and the absorbance was measured at $259 \mathrm{~nm}$ using $0.1 \mathrm{~N} \mathrm{HCl}$ as blank $[18,19]$.

The In vitro buoyancy was determined by floating lag time method the tablets were placed in $100 \mathrm{ml}$ beaker containing $0.1 \mathrm{~N} \mathrm{HCl} \mathrm{pH}$ 1.2). The time required for the tablets to rise to the surface and float was determined as floating lag time. The time between introduction of the dosage form and its buoyancy in $0.1 \mathrm{~N} \mathrm{HCl}$ and the time during which the dosage form remain buoyant were measured. The time taken for the dosage form to emerge on the surface of a medium called floating lag time (FLT) or buoyancy lag time (BLT) and total duration of time by which dosage form remain buoyant is called total floating time (TFT) [20, 21].

Dissolution test was carried out using USP II (electro lab) rotating paddle method (apparatus 2). The stirring rate was $50 \mathrm{rpm} .0 .1 \mathrm{~N} \mathrm{HC}$ $\mathrm{pH}$ 1.2) was used as dissolution medium $900 \mathrm{ml}$ and was maintained at $37 \pm 0.5{ }^{\circ} \mathrm{C}$. Samples of $5 \mathrm{ml}$ were withdrawn at predetermined time intervals, filtered and replaced with $5 \mathrm{ml}$ of fresh dissolution medium. The collected samples were suitably diluted with the dissolution fluid, wherever necessary and were analyzed for the quinapril $\mathrm{HCl}$ at $259 \mathrm{~nm}$ by using a double beam UV spectrophotometer [22-26].

The swelling index of tablets was determined by using $0.1 \mathrm{~N} \mathrm{HCl}(\mathrm{pH}$ 1.2) at room temperature. The swollen weight of the tablets was determined at predefined time intervals. The swelling index was calculated by the following equation:

$$
\text { Swelling index }(\mathrm{SI})=\frac{\mathrm{Wt}-\mathrm{Wo}}{\mathrm{Wo}} \times 100
$$

Where,

$\mathrm{Wt}=$ Weight of tablet at time $\mathrm{t}$.

Wo = Initial weight of tablet [27-30]

\section{Release kinetics of drug}

All the formulations were subjected to study the release kinetics. The drug release profile of all the batches was fitted to Zero order kinetics, first order kinetics, Higuchi Matrix model, KorsmeyerPeppas model and Hixson-Crowell model [31-35].

\section{Zero order kinetics}

Drug dissolution from pharmaceutical dosage forms that do not disaggregate and release the drug slowly (assuming that area does 
not change and no equilibrium conditions are obtained) can be represented by the following equation.

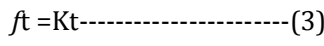

Where, $f t=$ the fraction of drug dissolved in time's

$\mathrm{K}=$ Rate Constant

$\mathrm{t}=$ Time

This model represents an ideal release profile in order to achieve the prolonged pharmacological action. This is applicable to dosage forms like transdermal systems, as well as matrix tablets with low soluble drugs, coated forms and osmotic systems.

\section{First order kinetics}

This model has also been used to describe absorption and/or elimination of some drugs, although it is difficult to conceptualize this mechanism in theoretical basis.

$$
\log Q_{t}=\log Q_{0}+K t / 2.303-
$$

Where $Q_{t}=$ Amount of drug released in time' $t$ '.

$\mathrm{Q}_{0}=$ Initial amount of drug in the solution.

$\mathrm{K}=$ Rate Constant.

\section{Higuchi matrix model}

This model is applicable to study the release of water soluble and low soluble drugs incorporated in semi-solid and/or solid matrices.

$$
f \mathrm{t}=\mathrm{Kt}^{1 / 2}
$$

Where, $f t=$ Amount of drug released in time' $t$ '

\section{Korsmeyer-peppas model}

This model is relating exponentially the drug release to the elapsed time $(\mathrm{t})$ :

$$
f t=a t^{n------------(6)}
$$

Where, $\mathrm{a}=$ constant incorporating structural and geometric characteristics of the drug dosage form.

$\mathrm{n}=$ diffusional exponent for the drug release that is dependent on the shape of the matrix dosage form.

\section{Hixson-crowell model}

The Hixson-Crowell model law describes the release from systems where there is a change in surface area and diameter of particles or tablets. For a drug powder consisting of uniformly sized particles, it is possible to derive an equation that expresses the rate of dissolution based on the cube root of the particles.

$$
\mathrm{Q}_{0}{ }^{1 / 3}-\mathrm{Q}_{\mathrm{t}^{1 / 3}}=\mathrm{K}_{\mathrm{HC}} \mathrm{t} \text {---------------(7)}
$$

Where,

$Q_{t}$ is the amount of drug released in time $t$,

$Q_{0}$ is the initial amount of the drug in tablet and $K_{\mathrm{HC}}$ is the rate constant for Hixson-Crowell rate equation.

The plot made: cube root of drug \% remaining in matrix vs. time (Hixson-Crowell model).

\section{Stability of formulation F4}

Stability is the essential factor for quality, efficacy and safety of drug product. The drug product with insufficient stability can result in a change of their physical (hardness, dissolution rate, phase separation) as well as chemical characteristics (formation of highrisk decomposition substances). Present study was carried out to check the dissolution behavior and physical appearance of optimized formulation F4. The formulation F4 was selected as an optimum and the stability study was carried out at accelerated conditions of $40 \pm 2$ ${ }^{\circ} \mathrm{C} / 75 \pm 5 \% \mathrm{RH}$ condition for a period of one month. Stability of formulation F4 was carried using Rimi stability chamber [36].

\section{RESULTS AND DISCUSSION}

In the present study, FDDS of quinapril $\mathrm{HCl}$ were prepared by using polymer hydroxypropyl methylcellulose (HPMC K4M), and using sodium bicarbonate and citric acid as the gas generating agent. FDDS tablets were prepared by direct compression method. The formulation was optimized by using different ratios of polymers and citric acid.

The prepared FDDS tablets were evaluated for its hardness, friability, uniformity of weight, uniformity of drug content, drugpolymer interaction studies, In vitro buoyancy studies and In vitro dissolution studies.

The pre-formulation parameter indicates there organoleptic properties and the melting point was found to be white, crystalline, bitter powder and $122{ }^{\circ} \mathrm{C}$ respectively. It is exactly same as the standard monograph mentioned in the USP.

\section{Full factorial design}

The responses of the formulation prepared by $3^{2}$ factorial designs are indicated in table 4 . The data clearly indicate that the $Q_{6}, Q_{12}$ and floating lag time are strongly dependent on the selected independent variables. The fitted equation relating the response $Q_{6}, Q_{12}$ and floating lag time the transformed factors are shown in equations 8, 9 and 10 respectively.

$$
\begin{array}{r}
\mathrm{Q}_{6}=54.550+0.4761 \mathrm{X}_{1-}-4.2085 \mathrm{X}_{2+} 1.2205 \mathrm{X}_{1} \mathrm{X}_{2-}- \\
2.6866 \mathrm{X}_{1}^{2}+0.8326 \mathrm{X}_{2}^{2}-------(8)
\end{array}
$$

$$
\left(\mathrm{R}^{2}=0.9981\right)
$$

$\mathrm{Q}_{12}=95.571+1.231 \mathrm{X}_{1}-0.833 \mathrm{X}_{2}+1.773 \mathrm{X}_{1} \mathrm{X}_{2}-8.844 \mathrm{X}_{1}{ }^{2}+1.704 \mathrm{X}_{2}{ }^{2}-\mathrm{-}_{-}$

$$
\left(R^{2}=0.9997\right)
$$

FLT $=98.166-3.291 \mathrm{X}_{1+} 4.500 \mathrm{X}_{2+} 6.750 \mathrm{X}_{1} \mathrm{X}_{2}+14.375 \mathrm{X}_{1}^{2}+0.750 \mathrm{X}_{2}{ }^{2--.}$

$$
\left(R^{2}=0.9990\right)
$$

The polynomial equation can be used to draw conclusion after considering the magnitude of coefficient and the mathematical sign it carries, (i.e., positive or negative). Positive or negative signs before a coefficient in quadratic models indicate a synergistic effect or an antagonistic effect for the factor. The high values of correlation coefficient (table 5) for $\mathrm{Q}_{6}\left(\mathrm{R}^{2}=0.9981\right), \mathrm{Q}_{12}\left(\mathrm{R}^{2}=0.9997\right)$, FLT $\left(\mathrm{R}^{2}=\right.$ $0.9990)$ indicate a good fit.

Equation 8 for $Q_{6}$ showed $b_{1}, b_{12}$ and $b_{22}$ positive but $b_{2}$ and $b_{11}$ negative this reveals that up to certain level decreases in $X_{2}$ and $X_{1}{ }^{1}$ from- 1 to +1 , increases $Q_{6}$ after that point in $Q_{6}$ seen. Percentage release at $6 \mathrm{hr}\left(\mathrm{Q}_{6}\right)$ was found to be 56.189 to 59.936 for batches containing $\mathrm{X}_{2}$ at-1 level, 46.361 to 51.274 for batches containing $\mathrm{X}_{2}+1$ level, 52.191 to 54.106 for batches containing $\mathrm{X}_{2}$ at 0 level.

Equation 9 for $Q_{12}$ showed $b_{1}, b_{12}$ and $b_{22}$ but $b_{2}$ and $b_{11}$ negative this reveals that up to certain level increases in $\mathrm{X}_{1}, \mathrm{X}_{12}$ and $\mathrm{X}_{2}{ }^{2}$ from1 to+1 increases $Q_{12}$. Percentage release at $12 \mathrm{hr}\left(Q_{12}\right)$ was found to be 88.657 to 98.234 for batches containing $X_{2}$ at- 1 level, 84.659 to 96.404 for batches containing $X_{2}+1$ level, 85.489 to 95.483 for batches containing $X_{2}$ at 0 level.

Equation 10 for FLT showed $b_{2}, b_{12}, b_{11}$ and $b_{22}$ positive, but $b_{1}$ negative this reveals that up to certain level increases in $\mathrm{X}_{2}, \mathrm{X}_{12}, \mathrm{X}_{1}{ }^{2}$ and $X_{2}{ }^{2}$ from- 1 to +1 increases FLT. Value of FLT was found to be 94 to 119 for batches containing $X_{2}$ at- 1 level, 104 to 121 to for batches containing $X_{2}+1$ level, 98 to 116 for batches containing $X_{2}$ at 0 level.

The main effects $\left(X_{1}\right.$ and $\left.X_{2}\right)$ represents the average result of changing one factor at a time from its low to high value. The interaction terms $\left(\mathrm{X}_{1}, \mathrm{X}_{2}, \mathrm{X}_{1} \mathrm{X}_{2}, \mathrm{X}_{1}{ }^{2}, \mathrm{X}_{2}{ }^{2}\right)$ shows the response changes when two or more factors are simultaneously changed.

The equation 8 suggest that the factor $\mathrm{X}_{1}$ has more significant effect on drug release at $Q_{6}$, therefore a high level of a factor is not selected for increasing drug release. From equation 9 it can conclude that single factor $\mathrm{X}_{1}$ not more effect on $\mathrm{Q}_{12}$, but factor in combination $\mathrm{X}_{1}$ 
and $X_{2}$ shows a positive effect. It means that the when the value of $X_{2}$ increases $Q_{12}$ decreases. From equation 10 negative sign of $X_{1}$ it concludes that FLT not depend on the value of $X_{1}$ but the magnitude of coefficient indicates that the factor $\mathrm{X}_{2}$ has a more favourable effect on the dependent variables [37].

\section{Drug excipients interaction and identification}

The wavelength of maximum absorbance was obtained at $259 \mathrm{~nm}$ (fig. 1).

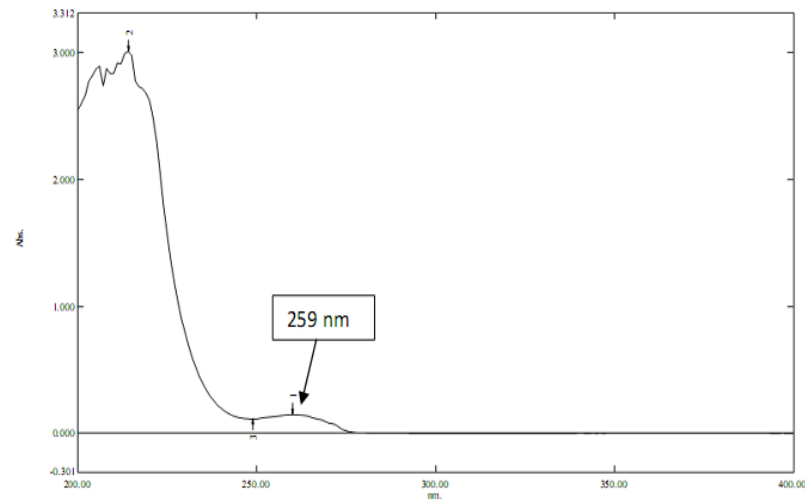

Fig. 1: UV Spectrum of quinapril HCl in 0.1 N HCL (Buffer of pH 1.2)

From the standard curve of quinapril $\mathrm{HCl}$ it was observed that the drug obeys Beer's law in the concentration range of $5-25 \mu \mathrm{g} / \mathrm{ml}$ in $0.1 \mathrm{~N} \mathrm{HCl}$ (buffer $\mathrm{pH} 1.2$ ) and straight line equation was obtained having the regression coefficient value of 0.9998 (fig. 2).

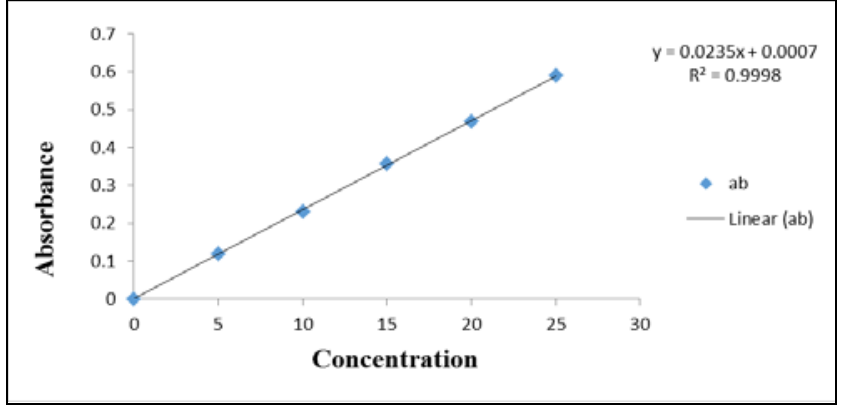

Fig. 2: Calibration curve of quinapril $\mathrm{HCl}$ in $0.1 \mathrm{~N} \mathrm{HCl}$ (Buffer of pH 1.2)

The combinations were compared with the spectra of pure drug and individual polymer. The principle peak obtained for the combinations were almost similar to that of the drug. The FTIR spectra of the drug HPMC K4M, drug-HPMC K4M and drug all excipients did not show any changes. The possibility of interaction was ruled out as there was no major shift in the absorption bands of drug and the formulation.

\section{FTIR}

$>$ FTIR spectrum for quinapril $\mathrm{HCl}$ indicated characteristics peaks belonging to measure functional groups such as principal peaks at wave numbers $1696 \mathrm{~cm}^{-1}, 1741 \mathrm{~cm}^{-1}, 1674 \mathrm{~cm}^{-1}, 1668 \mathrm{~cm}^{-1}, 1372 \mathrm{~cm}^{-}$ 1 and $750 \mathrm{~cm}^{-1}$ as shown in fig. 3 .

$>$ FTIR spectrum for HPMC K4M indicated characteristics peaks belonging to measure functional groups such principal peaks at wave numbers $2922.59 \mathrm{~cm}^{-1}, 3420.14 \mathrm{~cm}^{-1}, 1058.73 \mathrm{~cm}^{-1}$. The major FTIR peaks observed in HPMC K4M were $2922.59 \mathrm{~cm}^{-1}\left(2850 \mathrm{~cm}^{-1}\right.$ $\left.3000 \mathrm{~cm}^{-1}\right)(\mathrm{C}-\mathrm{H}), 3420.14 \mathrm{~cm}^{-1}\left(3300 \mathrm{~cm}^{-1}-3500 \mathrm{~cm}^{-1}\right)(\mathrm{N}-\mathrm{H})$, $1058.73 \mathrm{~cm}^{-1}\left(1000 \mathrm{~cm}^{-1}-1300 \mathrm{~cm}^{-1}\right)$ (C-O) as shown in fig. 4 .

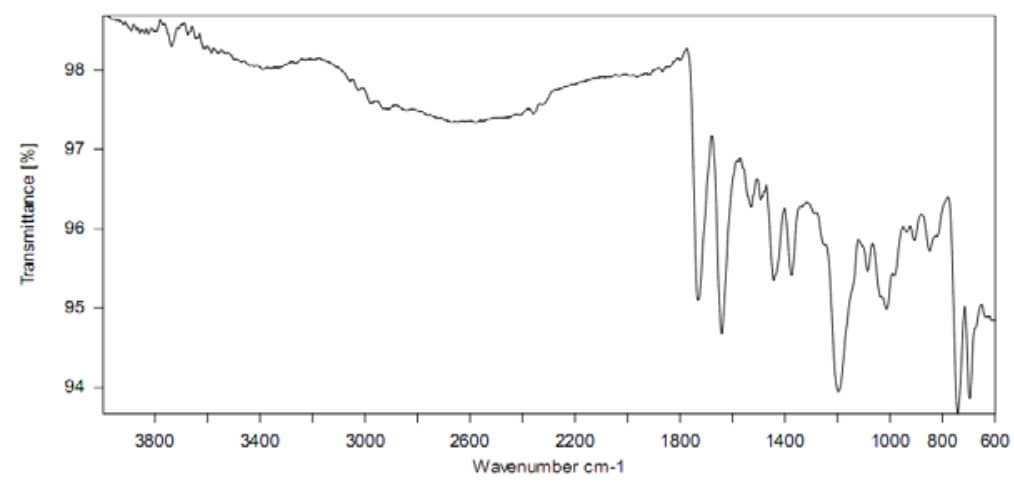

Fig. 3: FTIR spectra of quinapril HCl

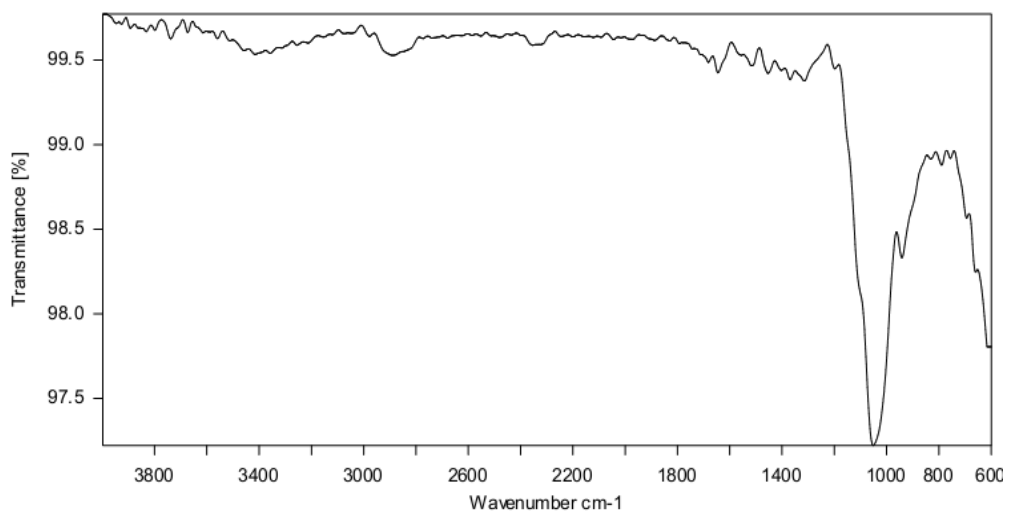

Fig. 4: FTIR spectra of HPMC K4M 


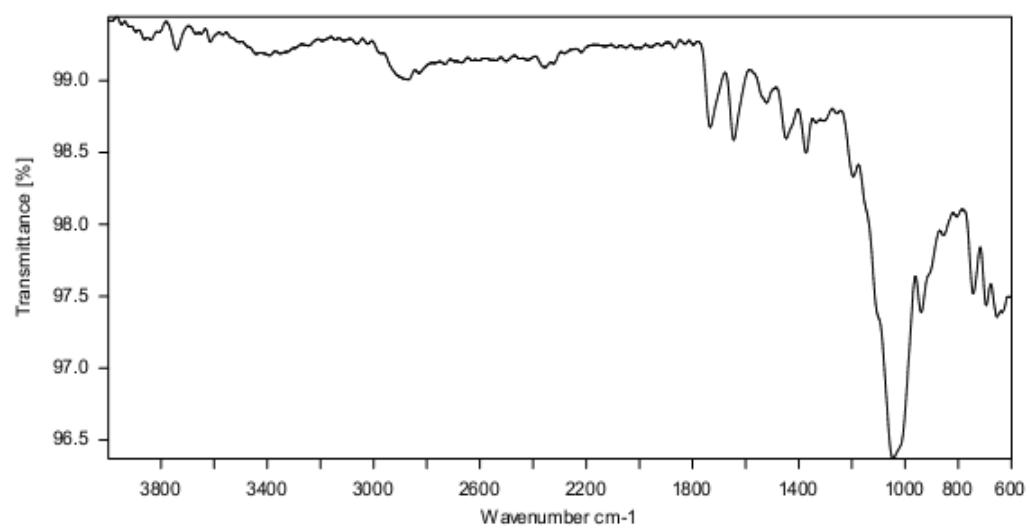

Fig. 5: FTIR spectra of quinapril HCl and HPMC K4M

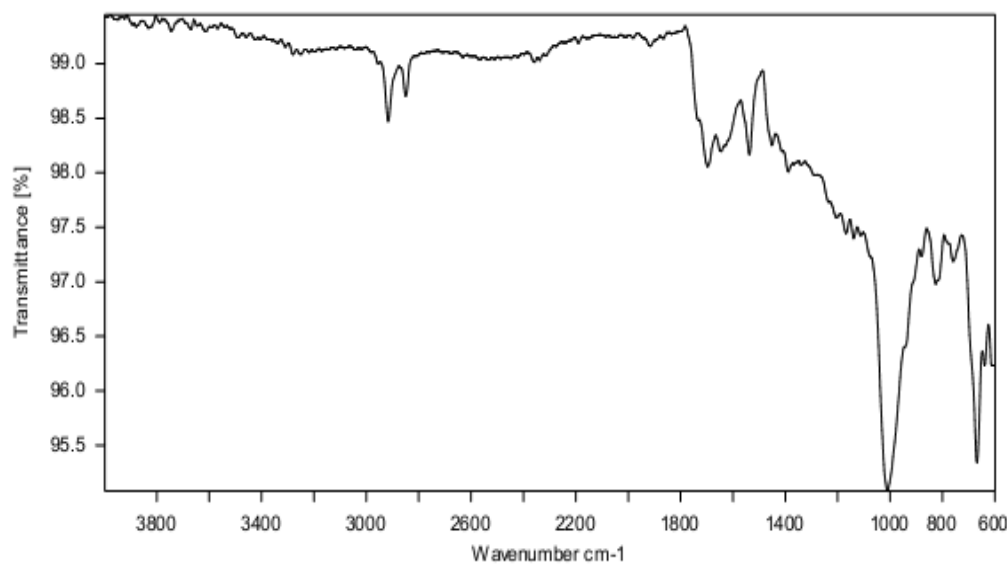

Fig. 6: FTIR spectra of quinapril $\mathrm{HCl}$ and all excipients

Formulation development

Table 4: Formulation and dissolution characteristics of batches in $3^{2}$ factorial designs

\begin{tabular}{llllll}
\hline Batch code & \multicolumn{2}{l}{ Coded values } & \% release at $\mathbf{6 h r}\left(\mathbf{Q}_{\mathbf{6}}\right)$ & \% release at 12hr $\mathbf{( \mathbf { Q } _ { \mathbf { 1 2 } } )}$ & Floating Lag time (sec) \\
\cline { 2 - 3 } & $\mathbf{X}_{\mathbf{1}}$ & $\mathbf{X}_{\mathbf{2}}$ & & & 119 \\
\hline F1 & -1 & -1 & 57.276 & 89.744 & 116 \\
F2 & -1 & 0 & 52.191 & 85.489 & 114 \\
F3 & -1 & +1 & 46.361 & 84.659 & 94 \\
F4 & 0 & -1 & 59.936 & 98.234 & 98 \\
F5 & 0 & 0 & 54.106 & 95.483 & 104 \\
F6 & 0 & +1 & 51.276 & 96.404 & 99 \\
F7 & +1 & -1 & 56.189 & 88.657 & 116 \\
F8 & +1 & 0 & 53.201 & 89.825 & 121 \\
F9 & +1 & +1 & 50.515 & 90.573 & \\
\hline
\end{tabular}

number of experiments $=9$

Where $\mathrm{X}_{1}$-Amount of HPMC K4M, $\mathrm{X}_{2}$-Amount of citric acid, $\mathrm{Q}_{6}$-percentage drug release at $6 \mathrm{~h}, \mathrm{Q}_{12}$-percentage drug release at $12 \mathrm{~h}$ and floating lag time (FLT) (sec)

Table 5: Multiple regressions output for dependent variables

\begin{tabular}{lllllll}
\hline Parameters & $\mathbf{B}_{\mathbf{0}}$ & $\mathbf{B}_{\mathbf{1}}$ & $\mathbf{B}_{\mathbf{2}}$ & $\mathbf{B}_{\mathbf{1 1}}$ & $\mathbf{B}_{\mathbf{2 2}}$ & $\mathbf{B}_{\mathbf{1 2}}$ \\
\hline $\mathrm{Q}_{6}$ & 54.550 & 0.4761 & -4.2085 & -2.6866 & 0.8326 & 1.2205 \\
$\mathrm{Q}_{12}$ & 95.5710 & 1.2316 & -0.8332 & -8.8448 & 1.7040 & 1.7737 \\
Floating lag time (sec) & 98.1667 & -3.2917 & 4.5000 & 14.3750 & 0.79818 & 0.99974 \\
\hline
\end{tabular}

number of experiments $=3$ 


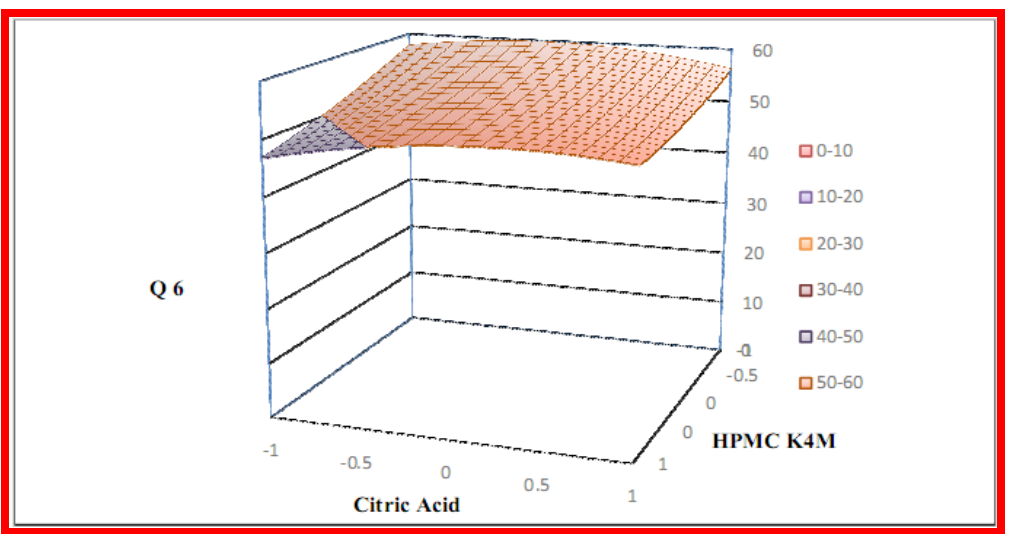

Fig. 7: Response surface plot for $Q_{6}$

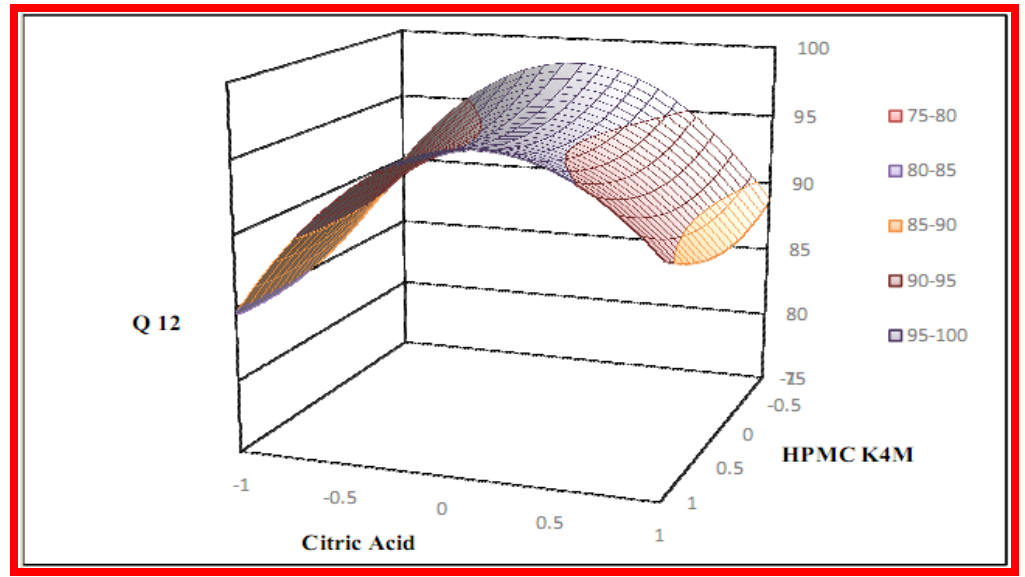

Fig. 8: Response surface plot for $Q_{12}$

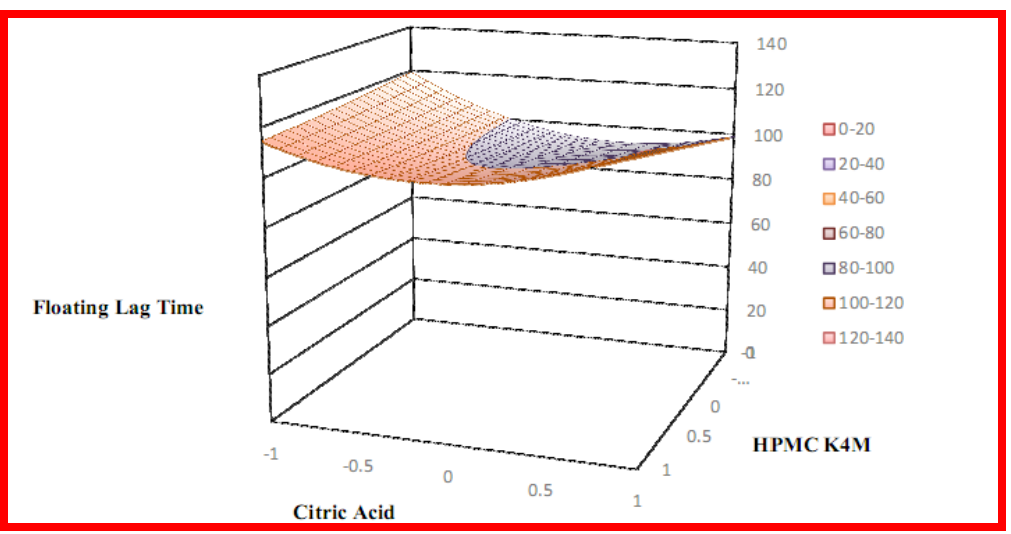

Fig. 9: Response surface plot for floating lag time

Fig. 7, 8 and 9 show the plot of the amount of HPMC K4M $\left(\mathrm{X}_{1}\right)$ and the amount of citric acid $\left(\mathrm{X}_{2}\right)$ versus $\mathrm{Q}_{6}, \mathrm{Q}_{12}$ and floating lag time respectively. The plot was drawn using PCP-Disso v3 software, India. The data demonstrate that both $X_{1}$ and $X_{2}$ affect the drug release $Q_{6}$, $\mathrm{Q}_{12}$ and floating lag time. It may also be concluded that the low level of $\mathrm{X}_{1}$ (amount of HPMC K4M) and the higher level of $\mathrm{X}_{2}$ (amount of citric acid) favor the preparation of floating sustained release quinapril $\mathrm{HCl}$ tablets. The high value of $\mathrm{X}_{1} \mathrm{X}_{2}$ coefficient also suggests that the interaction between $X_{1}$ and $X_{2}$ has a significant effect on $Q_{12}$. It can be concluded that the drug release pattern may be changed by appropriate selection of the $X_{1}$ and $X_{2}$ levels. An increase in the concentration of HPMC K4M $\left(\mathrm{X}_{1}\right)$ amount of citric acid $\left(\mathrm{X}_{2}\right)$, increase and decrease the rate of release of floating quinapril $\mathrm{HCl}$ tablet respectively.
Fig. 7 shows the influence of content of HPMC K4M and citric acid on $Q_{6}$. It was found that percentage drug release increase with decreases in the content of HPMC K4M and citric acid. Although the content of HPMC K4M and citric acid significant influence on the $Q_{6}$ it ranged from 46.361-59.936 from the graph it is observed that percentage drug release at $6 \mathrm{hr}\left(\mathrm{Q}_{6}\right)$ is increased.

Fig. 8 shows multiple regressions analysis for percentage drug release at $12 \mathrm{hr}\left(\mathrm{Q}_{12}\right)$ showed the significant contribution of both the factors on the response. Increasing the concentration of polymer $\left(\mathrm{X}_{1}\right)$ and citric acid $\left(\mathrm{X}_{2}\right)$ retardation of the drug release at $\mathrm{Q}_{12}$ is observed. 
Fig. 9 shows the influence of content of HPMC K4M and citric acid on floating lag time. It was found that FLT rises with increase with the content of HPMC K4M and citric acid. Although the content of HPMC $\mathrm{K} 4 \mathrm{M}$ and citric acid significant influence on the floating lag time it ranged from 94-121. The polynomial equation for floating lag time suggested that amount of citric acid and HPMC K4M has more significant effect on floating lag time. It may be due to the interaction between the gas generating agent sodium bicarbonate and dissolution medium $(0.1 \mathrm{~N} \mathrm{HCl}, \mathrm{pH} 1.2)$ which reduces FLT.

\section{Physical characteristics}

The powder blend of nine formulations (F1-F9) were evaluated for angle of repose, bulk density, tapped density, Carr's index and Hausner's ratio showed the pre-compressed blend has good flow property (table 6). The angle of repose of F1, F2 and F3 was found to be good in the range of 25-30 and similar was for F4, F5, F6, F7, F8 and F9. Formulation F1, F2, F3 showed increasing angle of repose from $25.70 \pm 0.14, \quad 24.77 \pm 0.17$ and $27.47 \pm 0.19$ respectively. Formulation F4, F5, F6, F7, F8 and F9 showed the same result as $26.56 \pm 0.27,24.30 \pm 0.29,26.56 \pm 0.16,27.47 \pm 0.14,23.96 \pm 0.89$ and
$25.76 \pm 0.93$. The lower angle of repose $23.96 \pm 0.89$ was shown by formulation F8. Formulations containing HPMC K4M showed good angle of repose. All formulations showed bulk density in the range of $0.397 \pm 0.36$ to $0.428 \pm 0.57$. All formulations showed tapped density in the range of $0.464 \pm 0.78$ to $0.523 \pm 0.80$. Carr's index up to 21 is considered of acceptable flow properties. A formulation containing HPMC K4 M showed good flow properties than other formulation. Formulations F1, F2, F3 showed good flow property as it showed Carr's ratio $15.05 \pm 0.11,11.506 \pm 0.46,14.85 \pm 0.35$ respectively.

Formulations F4, F5, F6 showed good flow property as it 19.02 \pm 0.91 , $14.85 \pm 0.35,15.40 \pm 0.39$ showed Carr's ratio respectively while F7, F8 and F9 showed good flow as it showed Carr's index of $18.16 \pm 0.44,18.42 \pm 0.10,14.43 \pm 0.96$. Hausner's ratio is the ratio of tapped density to bulk density. It was related to the interparticle friction, so it showed that powders with low interparticle fraction had ratios of approximately 1.25 indicating good flow.

All formulations showed acceptable flow property as it showed Hausner's ratio in the range of $1.13 \pm 0.36$ to $1.26 \pm 0.09$. All formulations showed acceptable flow properties.

Table 6: Physicochemical properties of quinapril HCl floating tablets

\begin{tabular}{|c|c|c|c|c|c|}
\hline $\begin{array}{l}\text { Batch } \\
\text { code }\end{array}$ & $\begin{array}{l}\text { Angle of } \\
\text { repose }(\theta)\end{array}$ & $\begin{array}{l}\text { Bulk density } \\
\left(\mathrm{gm} / \mathrm{cm}^{3}\right)\end{array}$ & $\begin{array}{l}\text { Tapped density } \\
\left(\mathrm{gm} / \mathrm{cm}^{3}\right)\end{array}$ & $\begin{array}{l}\text { Carr's index } \\
\text { (CI) }\end{array}$ & $\begin{array}{l}\text { Hausner's ratio } \\
\text { (HR) }\end{array}$ \\
\hline F1 & $25.70 \pm 0.14$ & $0.412 \pm 0.86$ & $0.485 \pm 0.58$ & $15.05 \pm 0.11$ & $1.17 \pm 0.18$ \\
\hline $\mathrm{F} 2$ & $24.77 \pm 0.17$ & $0.423 \pm 0.31$ & $0.478 \pm 0.96$ & $11.506 \pm 0.46$ & $1.13 \pm 0.36$ \\
\hline F3 & $27.47 \pm 0.19$ & $0.407 \pm 0.74$ & $0.478 \pm 0.26$ & $14.85 \pm 0.35$ & $1.17 \pm 0.47$ \\
\hline $\mathrm{F} 4$ & $26.56 \pm 0.27$ & $0.417 \pm 0.21$ & $0.515 \pm 0.62$ & $19.02 \pm 0.91$ & $1.23 \pm 0.50$ \\
\hline F5 & $24.30 \pm 0.29$ & $0.407 \pm 0.74$ & $0.478 \pm 0.26$ & $14.85 \pm 0.35$ & $1.17 \pm 0.47$ \\
\hline F6 & $26.56 \pm 0.16$ & $0.423 \pm 0.07$ & $0.500 \pm 0.19$ & $15.40 \pm 0.39$ & $1.18 \pm 0.20$ \\
\hline F7 & $27.47 \pm 0.14$ & $0.428 \pm 0.57$ & $0.523 \pm 0.80$ & $18.16 \pm 0.44$ & $1.22 \pm 0.16$ \\
\hline F8 & $23.96 \pm 0.89$ & $0.402 \pm 0.43$ & $0.507 \pm 0.69$ & $18.42 \pm 0.10$ & $1.26 \pm 0.09$ \\
\hline F9 & $25.76 \pm 0.93$ & $0.397 \pm 0.36$ & $0.464 \pm 0.78$ & $14.43 \pm 0.96$ & $1.16 \pm 0.87$ \\
\hline
\end{tabular}

number of experiments $(\mathrm{n})=3$, data given in mean $\pm \mathrm{SD}$ (Standard Deviation) $=3$

Formulated matrix tablets evaluated for physical parameters such as hardness, thickness, weight variation, friability and drug content the results are shown in table 7 . The formulation should be directed at optimizing tablet hardness without applying excessive pressure. The hardness of all formulations was found to be in the range of $5.2 \pm 0.20$ $\mathrm{kg} / \mathrm{cm}^{2}$ to $5.8 \pm 0.08 \mathrm{~kg} / \mathrm{cm}^{2}$. All the formulations passes weight variation test. The range of weight variation is $150 \pm 2.27$ to $150 \pm 3.37$. All the floating tablet system had acceptable friability as none of the tested formulae had percentage loss in tablets weight exceed 1\%. Friability below $1 \%$ is an indication of the good mechanical resistance of the tablets. Friability of all formulations ranges from 0.11 to 0.97 . Formulations F1, F2, F3 showed friability $0.21,0.11,0.32$ respectively. Formulations F4, F5, F5 showed friability $0.32,0.33,0.52$ respectively. Formulations F7, F8, F9 showed friability $0.42,0.89,0.97$ respectively. All formulations showed $\%$ friability less than $1 \%$. This ensures that tablets could withstand to the pressure, shocks during handling, transportation and shifting processes. Percentage drug content of quinapril $\mathrm{HCl}$ was determined by UV method and were found to be in the range of $97.85 \pm 1.04$ to $102.33 \pm 1.10$. The drug content of all matrix system was found to be within the limits.

Table 7: Post compression parameters

\begin{tabular}{|c|c|c|c|c|c|c|}
\hline $\begin{array}{l}\text { Batch } \\
\text { Code }\end{array}$ & $\begin{array}{l}\text { Weight variation } \\
\text { average Wt in } \\
(\mathrm{mg}) \pm \mathrm{SD}\end{array}$ & $\begin{array}{l}\text { Hardness } \\
\left(\mathrm{kg} / \mathrm{cm}^{2}\right) \\
\pm \mathrm{SD} \\
\end{array}$ & $\begin{array}{l}\text { Thickness } \\
\text { (mm) } \\
\pm \mathrm{SD} \\
\end{array}$ & $\begin{array}{l}\text { Diameter } \\
(\mathrm{mm}) \\
\pm \mathrm{SD}\end{array}$ & $\begin{array}{l}\text { Friability } \\
\text { (\%) }\end{array}$ & $\begin{array}{l}\text { Drug content } \\
\text { uniformity } \\
(\%) \pm \text { SD }\end{array}$ \\
\hline$\overline{F 1}$ & $150 \pm 3.19$ & $5.8 \pm 0.08$ & $3.0 \pm 0.06$ & $5.7 \pm 0.27$ & 0.21 & $98.10 \pm 1.18$ \\
\hline $\mathrm{F} 2$ & $150 \pm 3.21$ & $5.6 \pm 0.11$ & $3.1 \pm 0.12$ & $5.9 \pm 0.01$ & 0.11 & $100.50 \pm 1.29$ \\
\hline F3 & $150 \pm 2.27$ & $5.6 \pm 0.29$ & $3.13 \pm 0.06$ & $5.91 \pm 0.04$ & 0.32 & $102.33 \pm 1.10$ \\
\hline $\mathrm{F} 4$ & $150 \pm 3.06$ & $5.5 \pm 0.26$ & $3.1 \pm 0.06$ & $5.92 \pm 0.02$ & 0.32 & $100.50 \pm 1.28$ \\
\hline F5 & $150 \pm 2.57$ & $5.3 \pm 0.15$ & $3.1 \pm 0.1$ & $5.93 \pm 0.03$ & 0.33 & $99.95 \pm 1.47$ \\
\hline F6 & $150 \pm 3.37$ & $5.2 \pm 0.20$ & $3.16 \pm 0.15$ & $5.92 \pm 0.03$ & 0.52 & $97.85 \pm 1.04$ \\
\hline F7 & $150 \pm 2.75$ & $5.4 \pm 0.16$ & $3.06 \pm 0.12$ & $5.92 \pm 0.02$ & 0.42 & $99.40 \pm 1.58$ \\
\hline F8 & $150 \pm 2.75$ & $5.5 \pm 0.16$ & $3.16 \pm 0.08$ & $5.90 \pm 0.06$ & 0.89 & $102.05 \pm 1.49$ \\
\hline F9 & $150 \pm 2.76$ & $5.3 \pm 0.27$ & $3.0 \pm 0.08$ & $5.9 \pm 0.02$ & 0.97 & $98.45 \pm 1.16$ \\
\hline
\end{tabular}

number of experiments $(\mathrm{n})=3$, data given in mean $\pm \mathrm{SD}$ (Standard Deviation) $=3$

The swelling index was calculated with respect to time. As time increase, the swelling index was increased, because weight gain by tablet was increased proportionally with the rate of hydration. Later on, it decreased gradually due to the dissolution of outermost gelled layer of the tablet into dissolution medium. The direct relationship was observed between the swelling index and HPMC K4M increase, swelling index was increased which are shown in fig. 9 and 10. 


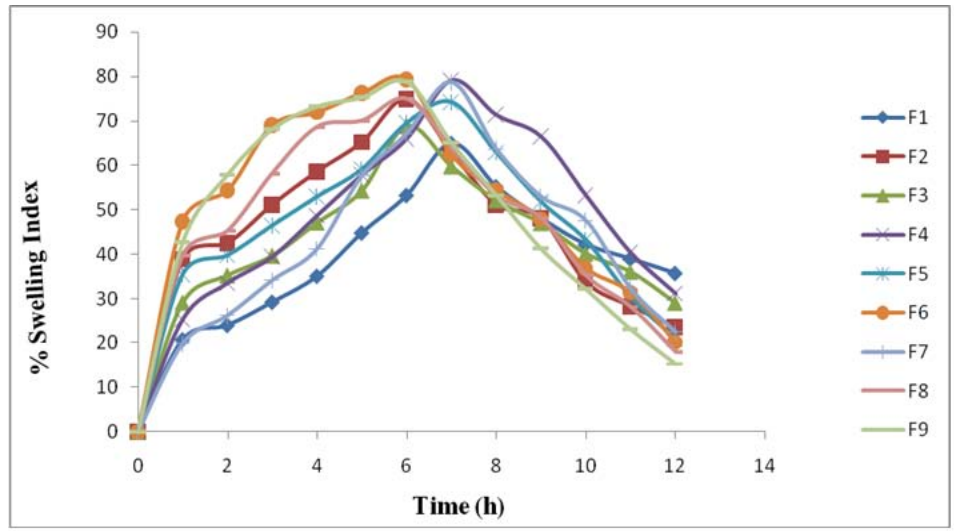

Fig. 10: Swelling index, number of experiments $=3$

\section{Evaluation of In vitro buoyancy study of the tablets}

The gas generated is trapped and protected within the gel, formed by hydration of polymer, thus decreasing the density of the tablet. As the density of the tablet falls below 1 , the tablet became buoyant. The results presented in table 8 revelled that HPMC K4M produced tablets with good gel strength, entrapping $\mathrm{CO}_{2}$ gas and imparting stable and persistent buoyancy. Floating lag time was in the range of
$94 \mathrm{sec}$ to $121 \mathrm{sec}$. All the factorial design batches showed good In vitro buoyancy, also the tablet remained buoyant for $12 \mathrm{~h}$, but the tablet actually floated throughout the entire study. In the fig. 11 shows a photograph of In vitro buoyancy study of the optimized batch F4 tablet at initial 0 min seen at the bottom of the beaker, at the $10 \mathrm{sec}$ the tablet was seen at the center of the beaker that is the floating lag time and at 2-3 min the tablet was seen at the surface of the beaker.

Table 8: Floating properties of quinapril HCl tablets

\begin{tabular}{llll}
\hline Formulation & Floating lag time (seconds) & Matrix integrity & Floating duration (h) \\
\hline F1 & 119 & $\checkmark$ & $>12$ \\
F2 & 116 & $\checkmark$ & $>12$ \\
F3 & 114 & $\checkmark$ & $>12$ \\
F4 & 94 & $\checkmark$ & $>12$ \\
F5 & 98 & $\checkmark$ & $>12$ \\
F6 & 104 & $\checkmark$ & $>12$ \\
F7 & 99 & $\checkmark$ & $>12$ \\
F8 & 116 & $\checkmark$ & $>12$ \\
F9 & 121 & $\checkmark$ & $>12$ \\
\hline
\end{tabular}

a number of experiments $=3$.

\section{In vitro drug release studies}

Besides the satisfactory buoyancy, the floating tablets are required to release quinapril $\mathrm{HCl}$ gradually over prolonged period. Hence, they were tested for release kinetics by conducting In vitro dissolution test.

The results obtaining In vitro release studies were plotted in a different model of data treatment as follows:

$>$ Cumulative percentage drug released vs. time (zero order kinetics)

$>$ Log Cumulative percentage drug remaining to be released vs. time (First-order rate kinetics)

$>$ Cumulative percent drug released vs. square root of time (Higuchi Matrix plot)

$>$ Log Cumulative percentage drug released vs. log time (Korsmeyer-Peppas plot)

$>$ Cube root of drug percentage remaining to be released vs. time (Hixson-Crowell model)

From the dissolution study, it was concluded that release from the matrix is largely dependent on the polymer swelling and drug diffusion. It was observed that all the tablets ascended to the upper one-third of the dissolution vessels within a short time and remained floated until the complete of release studies. The drug release study was carried out up to $12 \mathrm{~h}$. The percentage drug release from batch F1 to F9 vary from 84.659 to $98.234 \%$ because of increase in the concentration of polymer (HPMC $\mathrm{K} 4 \mathrm{M}$ ). High drug release is observed in F4 batch because of low concentration of polymer (HPMC K4M). A Large concentration of high viscosity polymer induces the formation of strong viscous gel layer that slowed down the rate of water diffusion into the tablet matrix, which may result in the retardation or decreases the drug release. Being water soluble polymers, they dissolve and form pores filled liquid in which drug can thereafter diffuse in the dissolution medium. All the formulations were designed as a dosage form for $12 \mathrm{~h}$. Dissolution profiles of all batches were shown in fig. 13-17.

From the dissolution study, it was concluded that release from the matrix is largely dependent on the polymer swelling and drug diffusion.

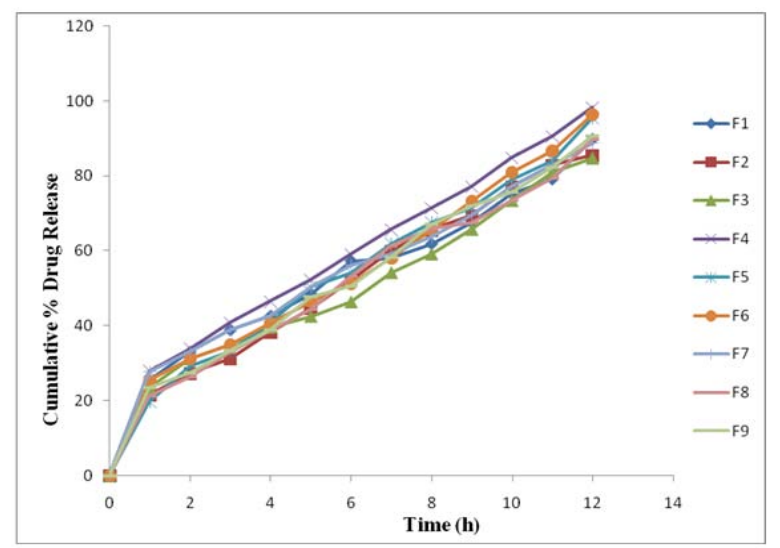

Fig. 11: Zero-order drug release kinetics for formulations F1-F9, number of experiments $=3$ 


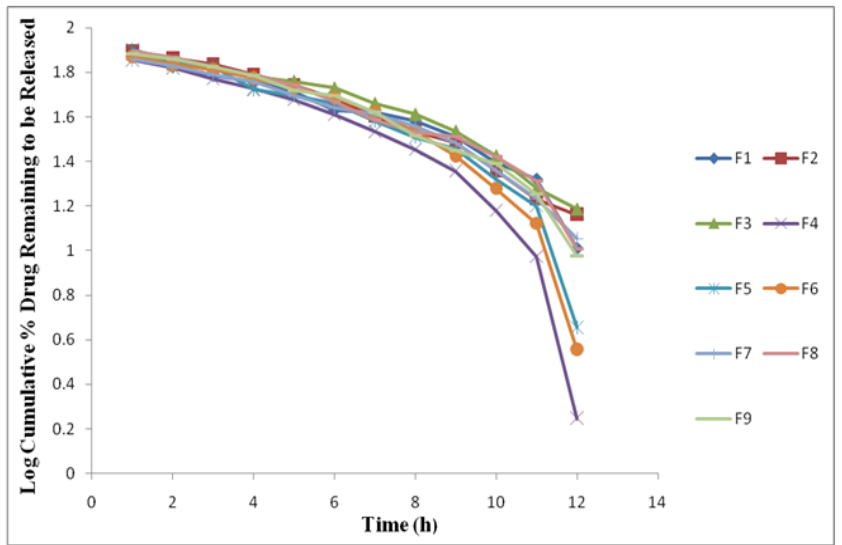

Fig. 12: First order drug release kinetics for formulations F1-F9, number of experiments $=3$

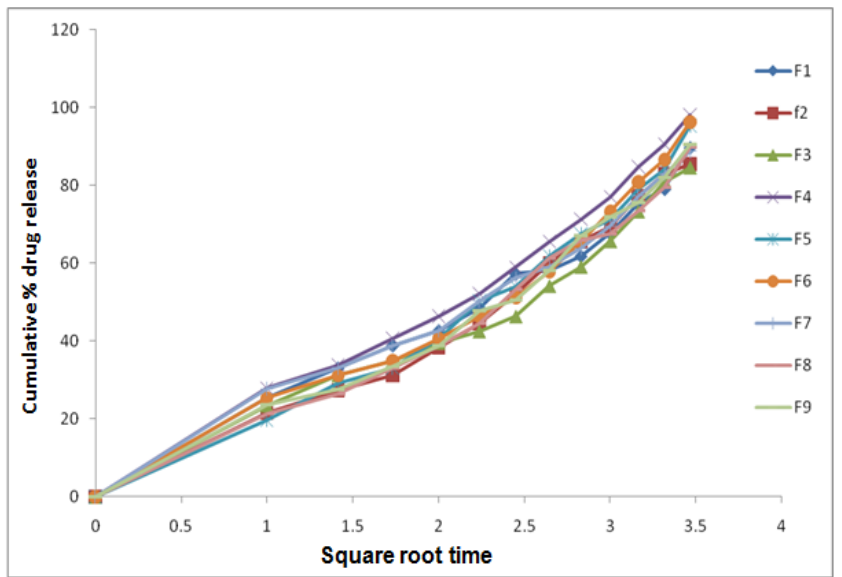

Fig. 13: Higuchi matrix drug release kinetics for formulations F1-F9, number of experiments $=3$

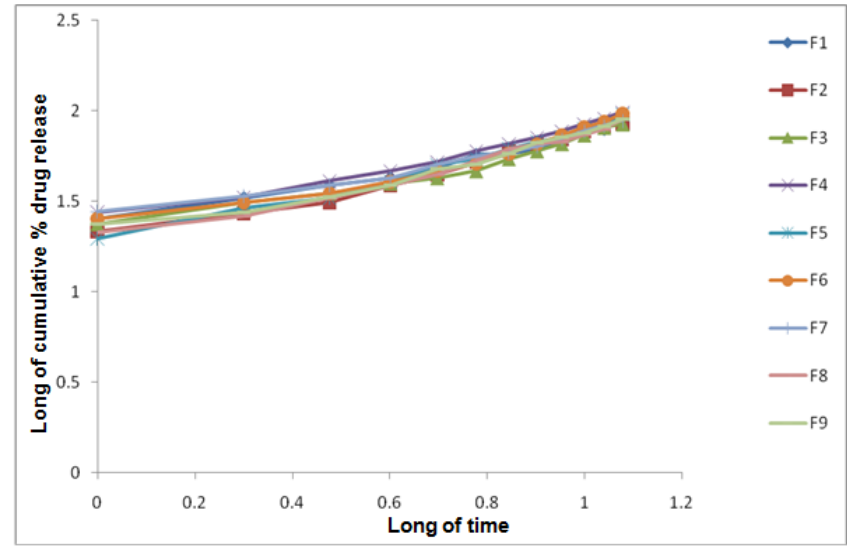

Fig. 14: Korsmeyer-peppas drug release kinetics for formulations F1-F9, number of experiments $=3$

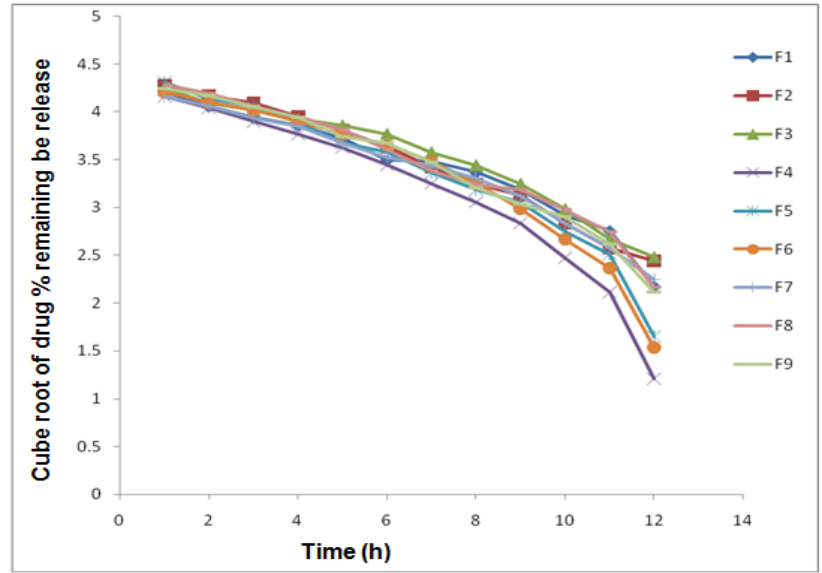

Fig. 15: Hixson-crowell drug release kinetics for formulations F1-F9, number of experiments $=3$

Table 9: Drug release kinetic data of quinapril $\mathrm{HCl}$ floating tablet

\begin{tabular}{|c|c|c|c|c|c|c|}
\hline $\begin{array}{l}\text { Formulation } \\
\text { code }\end{array}$ & $\begin{array}{l}\text { Zero } \\
\text { order } \\
\left(\mathbf{R}^{2}\right) \\
\end{array}$ & $\begin{array}{l}\text { First } \\
\text { order } \\
\left(\mathrm{R}^{2}\right) \\
\end{array}$ & $\begin{array}{l}\text { Higuchi } \\
\text { matrix } \\
\text { model }\left(R^{2}\right)\end{array}$ & $\begin{array}{l}\text { Korsmeyer- } \\
\text { peppas } \\
\text { model }\left(R^{2}\right)\end{array}$ & $\begin{array}{l}\text { Hixson- } \\
\text { crowell } \\
\text { model }\left(R^{2}\right)\end{array}$ & $\begin{array}{l}\text { Best } \\
\text { fit } \\
\text { model }\end{array}$ \\
\hline F1 & 0.946 & 0.880 & 0.946 & 0.961 & 0.937 & Korsmeyer-peppas \\
\hline $\mathrm{F} 2$ & 0.977 & 0.961 & 0.977 & 0.959 & 0.983 & Hixson crowell \\
\hline F3 & 0.961 & 0.914 & 0.961 & 0.982 & 0.948 & Korsmeyer-peppas \\
\hline $\mathrm{F} 4$ & 0.964 & 0.723 & 0.964 & 0.969 & 0.906 & Korsmeyer-peppas \\
\hline F5 & 0.978 & 0.822 & 0.979 & 0.941 & 0.924 & Higuchi matrix \\
\hline F6 & 0.973 & 0.792 & 0.973 & 0.991 & 0.896 & Korsmeyer-peppas \\
\hline F7 & 0.950 & 0.919 & 0.950 & 0.977 & 0.960 & Korsmeyer-peppas \\
\hline F8 & 0.973 & 0.904 & 0.972 & 0.953 & 0.956 & Zero order \\
\hline F9 & 0.975 & 0.909 & 0.977 & 0.970 & 0.958 & Higuchi matrix \\
\hline
\end{tabular}

number of experiments $=9$

Table 10: Drug release kinetics for korsmeyer-peppas model

\begin{tabular}{|c|c|c|c|c|}
\hline Formulations & $\mathbf{N}$ & $\mathbf{K}$ & $\mathbf{R}^{2}$ & Best fit model \\
\hline F1 & 0.5523 & 9.3295 & 0.961 & Korsmeyer-peppas \\
\hline $\mathrm{F} 2$ & 0.6890 & 7.0155 & 0.959 & Hixson-crowell \\
\hline F3 & 0.5885 & 8.4135 & 0.982 & Korsmeyer-peppas \\
\hline $\mathrm{F} 4$ & 0.5948 & 9.6093 & 0.969 & Korsmeyer-peppas \\
\hline F5 & 0.7112 & 7.0124 & 0.941 & Higuchi matrix \\
\hline F6 & 0.6153 & 8.4305 & 0.991 & Korsmeyer-peppas \\
\hline F7 & 0.5458 & 9.6580 & 0.977 & Korsmeyer-peppas \\
\hline F8 & 0.6612 & 7.3243 & 0.973 & Zero order \\
\hline F9 & 0.6531 & 7.6250 & 0.977 & Higuchi matrix \\
\hline
\end{tabular}

number of experiments $=3$ 
Based on the " $\mathrm{n}$ " values were ranging from 0.5458 to 0.7112 for optimized formulations, the drug release was found to follow Anomalous (Non-Fickian) diffusion. Anomalous diffusion indicates a coupling of the diffusion and erosion mechanism (Anomalous diffusion) and indicates that the drug release was controlled by more than one process. Comparative study of F1, F4 and F7 was done. F1, F4 and F7 formulations showed Anomalous diffusion (Non-
Fickian). Formulations F1, F3, F4, F6 and F7 showed the highest linearity with $\mathrm{r}^{2}$ value of $0.961,0.982,0.969,0.991$ and 0.977 which was best fitted to Korsmeyer-Peppas model. F2 show linearity with $\mathrm{r}^{2}$ value of 0.959 which was best fitted to Hixson-Crowell model. F8 show linearity with $\mathrm{r}^{2}$ value of 0.973 which was best fitted to Zero Order model. F5 and F9 show linearity with $\mathrm{r}^{2}$ value of $0.941,0.977$ which was best fitted to Higuchi Matrix model.

Table 11: Interpretation of diffusion release mechanisms

\begin{tabular}{lll}
\hline S. No. & Release exponent & Drug transport mechanism \\
\hline 1 & 0.5 & Fickian diffusion \\
2 & $0.5<\mathrm{n}<1$ & Anomalous (Non-Fickian) transport \\
3 & 1.0 & Case II Transport \\
4 & Higher than 1.0 & Super case II transport \\
\hline
\end{tabular}

\section{Stability study}

The present study was carried out to check the dissolution behaviour and physical appearance of optimised batch F4. The batch F4 was selected as an optimum batch and the stability study was carried out at accelerated conditions of $40 \pm 2{ }^{\circ} \mathrm{C} / 75 \pm 5 \% \mathrm{RH}$
Condition for a period of one month. And Stability of batch F4 was carried using Rimi stability chamber.

According to ICH guidelines, one-month stability studies conducted at controlled temperature $40 \pm 2{ }^{\circ} \mathrm{C}$ and humidity $75 \pm 5 \%$ RH showed negligible changes in results (table 12).

Table 12: Stability study of formulation F4

\begin{tabular}{lll}
\hline Time (h) & Cumulative \% drug release (Initial) & Cumulative \% drug release (After storage at $\mathbf{4 0}^{\circ} \mathbf{C}$ after $\mathbf{1}$ mo) \\
\hline 0 & 0.000 & 0.000 \\
1 & $25.728 \pm 0.21$ & $24.296 \pm 0.19$ \\
2 & $32.045 \pm 0.57$ & $30.971 \pm 0.49$ \\
3 & $39.854 \pm 0.48$ & $38.719 \pm 0.36$ \\
4 & $45.870 \pm 0.58$ & $44.873 \pm 0.54$ \\
5 & $52.967 \pm 0.11$ & $50.231 \pm 0.08$ \\
6 & $59.843 \pm 0.10$ & $57.316 \pm 0.07$ \\
7 & $64.859 \pm 0.52$ & $63.725 \pm 0.48$ \\
8 & $72.258 \pm 0.22$ & $69.984 \pm 0.18$ \\
9 & $77.832 \pm 0.29$ & $76.108 \pm 0.25$ \\
10 & $83.569 \pm 0.50$ & $81.324 \pm 0.47$ \\
11 & $91.230 \pm 0.85$ & $90.635 \pm 0.79$ \\
12 & $98.819 \pm 0.24$ & $97.681 \pm 0.19$ \\
\hline
\end{tabular}

Number of experiments $(n)=3$, data given in mean \pm SD (Standard Deviation $)=3$

\section{CONCLUSION}

From the present study, it was concluded that quinapril $\mathrm{HCl}$ floating drug delivery systems prepared by direct compression method using HPMC K4M as a polymer and citric acid and sodium bicarbonate as the gas generating agent. All the prepared tablet formulations were found to be good without capping and chipping. The present investigation described the influence of the concentration of polymer (HPMC K4M) and citric acid on quinapril $\mathrm{HCl}$ release using $3^{2}$ full factorial designs. The result of multiple regression analysis indicated that both factors $\mathrm{X}_{1}$ and $\mathrm{X}_{2}$ significantly affect the percentage drug release at $6\left(\mathrm{Q}_{6}\right)$ and $12\left(\mathrm{Q}_{12}\right)$ hour and FLT should be used to manufacture the tablet formulation with desired In vitro dissolution.

The In vitro dissolution profiles of all the prepared quinapril $\mathrm{HCl}$ floating formulations were found to extend the drug release over a period of 10 to $12 \mathrm{~h}$ and the drug release rate decreased with increase in polymer concentration. FTIR spectroscopic studies indicate no drug-excipients interaction in the prepared formulations. Comparing the all formulations, FDDS formulation of F4 was considered as an optimized formulation which exhibited $98.234 \%$ of drug release in $12 \mathrm{~h}$, and floating lag time of 94 seconds with a total floating time of $12 \mathrm{~h}$. From the result, it was observed that drug and polymer ratio influence the In vitro drug release and In vitro buoyancy of quinapril $\mathrm{HCl}$ floating tablets. Hence, the floating system of quinapril $\mathrm{HCl}$ is expected to provide the clinician with a new choice of safe and more bioavailable formulation in the management of hypertension.

\section{ACKNOWLEDGMENT}

We would like to thankful Marksans Pharmaceutical Ltd., Verna, Goa, India for providing the gift sample of quinapril $\mathrm{HCl}$ drug and also Sahyadri College of Pharmacy, Methwade, Sangola, Solapur, Maharashtra, India for proving all the facilities to carry out this research work successfully.

\section{CONFLICT OF INTERESTS}

\section{Declared none}

\section{REFERENCES}

1. Chaitanyaa K, Velmurugan S. Formulation and evaluation of levodopa effervescent floating tablets. Int J Pharm Pharm Sci 2015;7:189-93.

2. Mali AD, Bathe RS. Design and optimization of gastro retentive floating matrix tablets of an antihypertensive drug quinapril HCl. Int J Pharm Technol 2015; 7:9212-24.

3. Mali A, Jadhav S, Tambili A, Kargane V, Bathe R. Development and validation of a UV-spectrophotometric method for the estimation of quinapril hydrochloride in bulk and in its formulation. World J Pharma Res 2015; 4:1839-46.

4. Baviskar DT, Jain DK. Textbook of novel drug delivery system. $1^{\text {st }}$ edition India. Vol. 1. Nirali Prakashan; 2014. p. 11. 1-13.

5. Mali AD, Bathe RS. A review on gastro retentive floating drug delivery system. Ame J PharmTech Res 2015;5:107-32. 
6. Jagdale SC, Patil SA, Kuchekar BS. Design, development and evaluation of floating tablets of tapentadol hydrochloride using chitosan. Asian J Pharm Clin Res 2012;5:163-8.

7. Gonnabathula PK, Velmurugan S, Venkateswara Rao CH. Design and optimization of effervescent floating matrix tablet of quetiapine fumarate using $3^{2}$ factorial designs. J Biochem Pharmacol Res 2014;6:810-22.

8. Shahi S, Sonawane A, Vanamore S, Zadbuke N. Formulation and in vitro characterization of acyclovir floating matrix tablets: a factorial design study. J Appl Pharma Sci 2013;3:65-74

9. Shahi SR, Madkar VM, Kshirsagar PN, Khadbadi SS Development and evaluation of bilayer floating tablets of diltiazem HCl. Int J Pharm Pharm Sci 2014;6:62-5.

10. Khan ZA, Tripathi R, Mishra B. Floating elementary osmotic pump tablet (FEOPT) for controlled delivery of diethylcarbamazine citrate: a water-soluble drug. AAPS PharmSciTech 2011;12:1312-23.

11. Chordiya MA, Gangurde HH, Senthilkumaran K. Formulation and in vitro evaluation of effervescent floating matrix tablet of propafenone HCl. World J Pharm Pharma Sci 2013;2:5348-62.

12. Kavita K, Yadav SS, Tamizhamani T. Formulation and evaluation of floating tablets of RHCL using natural and synthetic polymers. Int J PharmTech Res 2010;2:1513-9.

13. Devarajan K, Rangasamy M, Selvaraj J, Natesan S. Development and evaluation of floating tablets of ciprofloxacin HCl. Int J Pharma Alli Sci Arch 2012;201:17-25.

14. Senthil A, Suresh Kumar $P$, Narasimha R, Mohideen $S$. Formulation and evaluation of gastric oral floating tablet of glipizide. Int I Life Sci Biotechnol Pharma Res 2010;1:108-13.

15. Audumbar Digambar Mali, Ritesh Suresh Bathe. A review on gastro retentive floating tablets of Quinapril $\mathrm{HCl}$. Int J Adv Pharma 2014;3:28-31.

16. Devi AN, Hadi MA, Rajitha P, Sharma JVC, Srinivasa Rao A. Formulation and evaluation of floating controlled release tablets of imatinib mesylate using hydrophilic matrix system. Int J Pharm Pharma Sci 2012;5:271-7.

17. Kumar S, Das M, Gupta KS, Kumar R, Chongdar A, Ghosh LK Design, development, optimization and evaluation of gastroretentive floating tablets of atenolol. Pharm Lett 2013;5:436-56.

18. Bhoi P, Dash RK, Dalai MK. Formulation and in vitro evaluation of oral floating matrix tablets of diclofenac sodium. Int J PharmTech Res 2010;2:2420-8.

19. Patel VF, Patel NM. Intragastric floating drug delivery system of cefuroxime axetil: in vitro evaluation. AAPS PharmSciTech 2006;7:1-7.

20. Murtaza G, Ullah H, Khan SA, Mir S, Khan AK, Nasir B, et al. Formulation and in vitro dissolution characteristics of sustained-release matrix tablets of tizanidine hydrochloride. Trop J Pharma Res 2015;14:219-25.

21. Nayak RK, Manjunath B, Swamy VB, Senthil A, Thakkar HK Design and evaluation of sustained release floating tablets of loratadine. Asian J Biochem Pharm Res 2011;3:105-24.

22. Jain SK, Gupta A. Development of gelucire 43/01 beads of metformin hydrochloride for floating delivery. AAPS PharmSciTech 2009;10:1128-36.

23. Nayak AK, Das B, Maji R. Gastroretentive hydrodynamically balanced systems of ofloxacin: in vitro evaluation. Saudi Pharma J 2013;21:113-7.
24. Lingam M, Thadisetty A, Venkateswarlu V, Rao YM. Design and evaluation of a novel matrix type multiple units as biphasic gastro retentive drug delivery systems. AAPS PharmSciTech 2008;9:1253-61.

25. Murtaza G, Ullah H, Khan SA, Mir S, Khan AK. Formulation and in vitro dissolution characteristics of sustained-release matrix tablets of tizanidine hydrochloride. Trop J Pharma Res 2015;14:219-25.

26. Meka L, Kesavan B, Chinnala KM, Vobalaboina VV, Yamsani YR Preparation of a matrix type multiple-unit gastro retentive floating drug delivery system for captopril based on gas formation technique: in vitro evaluation. AAPS Pharm Sci Technol 2008;9:612-9.

27. Merchant HA, Shoaib HM, Tazeen J, Yousuf R. Once-daily tablet formulation and in vitro release evaluation of cefpodoxime using hydroxypropyl methyl cellulose: a technical note. AAPS PharmSciTech 2006;7:1-6.

28. Hussain MN, Masum AA, Akhter S, Sharmin F. Formulation and evaluation of gastro retentive floating tablets of simvastatin using hydrophilic rate retardant. Bangla Pharma J 2012;15:119-26.

29. Pawar HA, Gharat PR, Dhavale RV, Joshi PR, Rakshit PP. Development and evaluation of gastro retentive floating tablets of an antihypertensive drug using hydrogenated cottonseed oil. ISRN Pharm 2013;2:1-9.

30. Kumar VD, Srinivas $\mathrm{K}$, Mahesh $\mathrm{CH}$, Shirish V, Raju B. Hepatoprotective activity of silymarin floating drug delivery system against anti-tuberculosis drug. Int J Pharm Technol 2010;2:233-44

31. Mali AD, Bathe RS, Patil M. Floating microspheres: a novel approach in drug delivery system. GCC J Sci Tech 2015; 1:134-53.

32. Mali AD, Bathe RS. An updated review on micro balloon for a better approach in gastro retention. Asian J Pharm Sci 2015;5:1-5.

33. Lature S, Patil M, Mali A. Development and evaluation of sustained release matrix tablets of naproxen. Pharm Lett 2015;7:270-9.

34. Mali AD, Bathe RS. A review on the sustained release drug delivery system. GCC J Sci Technol 2015;1:107-23.

35. Choure S, Patil M, Hake G, Mali A. Formulation and evaluation of floating tablets of nizatidine. Int J Res Ayurveda Pharm 2015;6:290-8

36. Nimbalkar M, Jadhav S, Patil M, Mali A, Hake G. Development and evaluation of floating tablets of norfloxacin. Indo Am Pharm Res 2015;5:995-1006.

37. Patil MS, Vidyasagar G, Patil VB. Formulation, optimization and evaluation of floating tablets clarithromycin. Int J Pharm Pharm Sci 2015;7;320-6.

\section{How to cite this article}

- $\quad$ Audumbar Digambar Mali, Ritesh Suresh Bathe. Development and evaluation of gastro retentive floating tablets of a quinapril HCL by direct compression technique. Int J Pharm Pharm Sci 2017;9(8):35-46. 